\title{
CEREBROPROTECTIVE PROPERTIES OF ADEMOL IN TRAUMATIC BRAIN INJURY
}

\section{S.I. Semenenko, H.I. Khrebtii*, A.I. Semenenko}

National Pirogov Memorial Medical University, Vinnytsia, Ukraine

*Higher Education Institution of Ukraine «Bukovinian State Medical University», Chernivtsi, Ukraine

Key words: traumatic brain injury, cerebroprotective effect, Ademol, magnesium sulfate, neurological deficit.

Bukovinian Medical Herald. V.24, № 2 (94). P. 159-166.

\section{DOI:}

10.24061/2413-0737.

XXIV.2.94.2020.58

E-mail: semenenkos1@ rambler.ru
The goal of the work - to compare the effect of adamantine 1-adamantylethyloxy-3-morpholino-2-propanol hydrochloride (Ademol) derivative and magnesium sulfate on mnestic function and neurological deficit in an experimental model of traumatic brain injury.

Material and methods. The therapeutic effect of Ademol on modulated traumatic brain injury was evaluated with the use of doses of 1,2 and $4 \mathrm{mg} / \mathrm{kg}$ intravenously. Pseudoperated animals received $0.9 \% \mathrm{NaCl}$ solution based on the volume of the most effective dose of Ademol. As a drug for the control group we used $0.9 \% \mathrm{NaCl}$ solution at a dose of $2 \mathrm{ml} / \mathrm{kg} i / \mathrm{v}$ and in the same mode. Neurological deficit in rats with traumatic brain injury was evaluated on the first day and at the end of the acute period (on the eighth day) on the stroke-index C.P. McGrow scale. The animals' ability to learn and remember the aversive stimulus was examined in conditional reaction of passive avoidance test. The technique is based on the innate instinct of rats to a limited darkened space. The conservation of the conditioned responce was checked in a day by the change of the latent time of rat entry to the dark compartment. We also noted the number of animals that tried to enter the dark compartment but did not complete the attempt.

Results. While analyzing the effect of course therapy with Ademol solution on the degree of de-escalation of neurological deficiency, it can be noted that by this property the investigated drug outweighed the magnesium sulfate solution on the first day of application by $24 \%$ and on the eighth day by $30 \%(p<0.05)$. Regarding the restoration of mnestic functions in traumatic brain injury, the eight-day treatment of rats with magnesium sulfate solution somewhat improved memory, but was inferior to the efficacy of Ademol, which approximated the results of the conditional reaction of passive avoidance test to the results of pseudoperated animals.

Conclusions. The results of the experimental study make it possible to confirm the lack of reliable effectiveness of using magnesium sulfate in the correction of neurological deficiency at traumatic brain injury in rats. Ademol, unlike the magnesium sulfate solution, contributed to the reduction of the severity of neurological disorders, which was accompanied by an improvement of mnestic functions in animals on the eighth day of traumatic brain injury.

\section{Ключові \\ слова: черепно- \\ мозкова травма, церебропротекторний вплив, Адемол, магнію сульфат, неврологічний дефiųum.}

Буковинський медичний вісник. T.24, № 2 (94). C. 159-166.

\section{ЦЕРЕБРОПРОТЕКТОРНІ ВЛАСТИВОСТІ АДЕМОЛУ ПРИ ЧЕРЕПНО-МОЗКОВІЙ ТРАВМІ}

\section{С.I. Семененко, Г.І. Хребтій, А.І. Семененко}

Мета роботи - порівняти вплив похідної адамантану 1-адамантилетилокси-3-морфоліно-2-пропанолу гідрохлориду (Адемолу) та магнію сульфату на мнестичну функиію та неврологічний дефіцит на експериментальній моделі черепно-мозкової травми. матеріал і методи. Терапевтичну дію Адемолу на змодульованій черепно-мозковій травмі оцінювали при застосуванні доз 1, 2 та 
4 мг/кг внутрішньовенно. Псевдооперовані тварини отримували 0,9\% розчин $\mathrm{NaCl}$ із розрахунку до об'єму найбільш ефективної дози Адемолу. Як лікарський засіб для контрольної групи застосовували 0,9\% розчин $\mathrm{NaCl}$ у дозі 2 мл/кг в/в і у тому ж режимі. Неврологічний дефічит у щурів із черепно-мозковою травмою оцінювали на першу добу та наприкінці гострого періоду (на восьму добу) за шкалою stroke-index C.P. McGrow. Здатність тварин до навчання та запам'ятовування аверсивного стимулу досліджували в тесті умовної реакиії пасивного уникання. Методика заснована на природженому інстинкті шурів до обмеженого затемненого простору. Збереження умовної реакиії перевіряли через добу за зміною латентного часу входу шура до темного відсіку. Також відзначали кількість тварин, які намагались увійти до темної камери, але не завершили спроби.

Результати. Аналізуючи вплив курсової терапії розчином Адемолу на ступінь деескалації неврологічного дефіииту, можна зазначити, що за иією властивістю досліджуваний препарат переважав розчин магнію сульфату на першу добу застосування на 24\% та на восьму добу - на 30\% (p<0,05). Щодо відновлення мнестичних функиій при черепно-мозковій травмі, восьмиденна терапія щурів розчином магнію сульфату дещо покращувала пам'ять, але поступалась за ефективністю Адемолу, який наближав показники тесту умовної реакиї пасивного уникання до результатів псевдооперованих тварин.

Висновки. Результати проведеного експериментального дослідження дають можливість стверджувати про відсутність достовірної ефективності застосування магнію сульфату щодо корекиії неврологічного дефіииту при черепно-мозковій травмі у щурів. Адемол, на відміну від розчину магнію сульфату, сприяв зменшенню виразності неврологічних порушень, що супроводжувалося покращенням мнестичних функиій у тварин на восьму добу черепно-мозкової травми.

\section{Ключевые}

слова: черепномозговая травма, церебропротекторное влияние, Адемол, магния сульфат, неврологический дефиичт.

Буковинский медицинский вестник. T.24, № 2 (94). C.159-166.

\section{ЦЕРЕБРОПРОТЕКТОРНЫЕ СВОЙСТВА АДЕМОЛА ПРИ ЧЕРЕПНО-МОЗГОВОЙ ТРАВМЕ}

\section{С.И. Семененко, Г.И. Хребтий, А.И. Семененко}

Цель работы - сравнить влияние производной адамантана 1-адамантилетилокси-3-морфолино-2-пропанола гидрохлорида (Адемола) и магния сульфата на мнестическую функиию и неврологический дефицит на экспериментальной модели черепно-мозговой травмы. материал и методы. Терапевтическое действие Адемола на смоделированной черепно-мозговой травме оценивали при применении доз 1, 2 и 4 мг / кг. Псевдооперированые животные получали 0,9\% раствор NaCl из расчета к объему наиболее эффективной дозы Адемола. В качестве лекарственного средства для контрольной группь применяли 0,9\% раствор $\mathrm{NaCl}$ в дозе 2 мл / кг в/в, в том же режиме. Неврологический дефицит у крыс с черепно-мозговой травмой оценивали в первые сутки и в конце острого периода (на восьмые cутки) по шкале stroke-index C.P. McGrow. Cпособность животных к обучению и запоминанию аверсивного стимула исследовали в тесте условной реакичи пассивного избегания. Методика основана 
на врожденном инстинкте крыс к ограниченному затемненному пространству. Сохранение условной реакции проверяли через сутки по изменению латентного времени входа крысы до темного отсека. Также отмечали количество животных, которые пытались войти в темную камеру, но не завершили попьтку.

Результаты. Анализируя влияние курсовой терапии раствором Адемола на степень деэскалации неврологического дефицита, можно отметить, что за этим свойством исследуемый препарат преобладал раствор магния сульфата в первые сутки применения на 24\% и на 30\% на восьмые сутки ( $<$ <0,05). По восстановлению мнестических функиий при черепно-мозговой травме, восьмидневная терапия крыс раствором магния сульфата несколько улучшала память, но уступала по эффективности Адемолу, который приближал показатели теста условной реакиии пассивного избегания к результатам псевдооперированых животных.

Выводы. Результаты проведенного экспериментального исследования дают возможность утверждать об отсутствии достоверной эффективности применения магния сульфата относительно коррекции неврологического дефицита при черепно-мозговой травме у крыс. Адемол, в отличие от раствора магния сульфата, способствовал уменьшению выраженности неврологических нарушений, что сопровождалось улучшением мнестических функиий у животных на восьмые сутки черепно-мозговой травмы.

Introduction. According to the Consensus on studies of brain diseases in Europe, more than 700,000 Europeans suffer from traumatic brain injury (TBI) [1]. Annually, of the total number of people first recognized as disabled due to cerebral injuries, traumatic genesis of disability is reported in more than 35\% [2]. Disability due to TBI is usually long-term, and in $30-35 \%$ of cases it is established indefinitely [3]. Development and implementation of emergency neurology and neurosurgical practice of new drugs capable of influencing the secondary damage of neurons in patients with TBI into doctors' practice has let significantly influence the recovery of such patients, reduce the length of stay in intensive care departments, reduce the mortality, improve the rehabilitation and the restoration of cognitive functions. The high expectations of modern medicine for neuroprotective therapy have stimulated scientists all over the world to actively seek new effective means of influencing the pathophysiological cascades of neuronal injury development $[4,5]$. For today, the imbalance of neurotransmitters is the most promising target for pharmacological effects on secondary neuronal damage [6]. Studies have shown that at TBI there is an increased synthesis of neurotransmitters, which correlates with a deterioration in the prognosis of a patient with brain injury [7]. The greatest damaging effect is inherent in glutamate, which triggers the excitotoxicity cascade [8]. Hyperactivation of NMDA and AMPA receptors causes an excessive intake of calcium ions into the cell with the activation of phospholipases, endonuclease, caspase, etc.; which destroy cytosolic structures and lead to cell apoptosis [9]. Many studies have demonstrated the efficacy of glutamate NMDA receptor antagonists. Blockade of
NMDA receptors is considered to be one of the main links of neuroprotection [10].

The goal of the work. To compare the effectiveness of using adamantane 1-adamantylethyloxy-3-morpholino2-propanol hydrochloride (Ademol) and magnesium sulfate derivatives for correction of mnestic function and neurological deficit in a model of traumatic brain injury in rats.

Material and methods. The experiments were conducted on white male rats weighing 160-190 g, which were under standard vivarium conditions, in accordance with the ethical standards of conducting experimental studies. The TBI experimental model was caused by the action of a carbon dioxide stream under pressure created using a gas balloon pneumatic gun. Rats under conditions of propofol anesthesia $(60 \mathrm{mg} / \mathrm{kg})$, after catheterization of the femoral vein and adjusting the possibility of making infusion through the infusomat, were performed right-sided bone-plastic trepanation of the skull of the projection of the middle cerebral artery, with a hole diameter of $5 \mathrm{~mm} 2$. After fixation of the rat in a position on the abdomen upside down, a shot was taken from a fixed distance (close-up shot), the bone fragment on the periosteum together with aponeurosis, was returned to the site and the wound was sutured in layers. Thus, severe TBI was modeled.

The therapeutic effect of Ademol on model TBI was evaluated at applying doses of 1,2 , and $4 \mathrm{mg} / \mathrm{kg}$ intravenously. Pseudoperated animals received $0.9 \% \mathrm{NaCl}$ solution from calculation to the most effective in volume dose of Ademol. As a drug for the control group we used $0.9 \% \mathrm{NaCl}$ solution at a dose of $2 \mathrm{ml} / \mathrm{kg}$ i/v in the same mode. 
Neurological deficit in rats with severe TBI (as well as other functional and laboratory parameters) was evaluated on the scale of stroke-indexC.P. McGrow on the first day and at the end of the acute period $12 \mathrm{~h}$ after the last injection of drugs (on the 8th day) [10]. The severity of the condition was defined by the sum of the corresponding points: up to 3 points - a mild degree, from 3 to 7 points - an average degree, above 7 points - a severe degree. There were tremors, paresis, limb paralysis, ptosis, arena movements, lateral position, the ability of rats to hold on rods with a diameter of 15 $\mathrm{cm}$, rotating at a speed of $3 \mathrm{rpm}$. We tested animals on the 8th day, determined the amount of points (unilateral half-ptosis - 0.5 points; unilateral ptosis - 1 point; tremor - 0.5 points; arena movements - 0.5 points; paresis of limbs (for each limb) - 1 point; limb paralysis (for each limb) - 2 points; lateral position - 3 points; inability to stay on the rotating rod for 4 minutes - 3 points). The ability of animals to learn and memorize aversive stimulus was investigated in a same period (8th day) of TBI in a conditional reaction of passive avoidance test (CRPA) [11]. The technique is based on the inborn instinct of rats to a limited darkened space. Rats were trained in a two-chamber facility consisting of two compartments, light and dark. The animal was placed in the light compartment, latent time of entry into the dark compartment was recorded, where the rat received electrical irritation and ran out into the light compartment. CRPA conservation was checked in 24 hours by the change of the latent time of rat entry to the dark compartment. We also noted the number of animals that tried to enter the dark compartment but did not complete the attempt.

Quantitative data were processed using the statistical processing program StatPlus 2009. We used parametric criterion $t$ Student in cases of normal distribution of the variation series, nonparametric criterion W White - in cases of its absence, paired criterion Ť Wilcoxon - to determine changes in dynamics within the group, angular transformation Fisher - when accounting for the results in an alternative form (presence or absence of a certain sign) [12]. The differences were considered statistically significant at $\mathrm{p}<0.05$.

Results and Their Discussion. Most researchers view magnesium as an ion with neuro-sedative properties due to its ability to block the nerve impulse [13]. In clinical practice, magnesium sulfate has been long used as an antihypertensive agent and a means of reducing intracranial pressure [14]. It has been established that $\mathrm{Mg} 2$ + ions block NMDA-associated channels in a potentialdependent way and, by engaging with glutamate in noncompetitive antagonism, inhibit its release, inhibiting excitotoxicity [15]. Despite the fact that magnesium sulfate is a long-known medicinal product and, according to many neurologists, "obsolete approach", the study of its pathophysiological effects continues today, opening new horizons for using in clinical practice. In 2018, while studying on rats, K.S. Vujoviis, S. Vuskoviis,
Durovic A., et al. found that inhibition of neuronal NO synthase is one of the pathophysiological mechanisms of the development of hypothermia with the infusion of a combination of ketamine and magnesium sulfate [16]. In preclinical studies, a significant decrease in ischemia zone was observed when using magnesium sulfate; in patients with ischemic stroke, the use of this agent in the first hours of the disease improved the end result, and at the TBI simulation significantly reduced the level of glutamate and apoptosis of neurons [17]. However, the results of the multicenter MASH-II study that studied the effect of magnesium sulfate on the delay of cerebral ischemia due to subarachnoid hemorrhage of aneurysmal origin cannot fail to attract the attention of the scientific community [18]. The injection of magnesium sulfate did not show a significant difference in the effect on the zone of ischemia and ischemic injury and this fact gave an impetus to scientific disputes about the prospects of further use of the drug in neurological and neurosurgical practice [19]. Our interest was aroused by a thorough, literary review of all the successful and failed studies of using magnesium sulfate in neuro-practice published by I. Lingam, N.J.Robertson in 2018 [19]. Scientists have come to the conclusion that further studies of this drug are needed, studies that would reveal to science the additional possibilities of its prescription, and the prescription of magnesium sulfate at TBI is still a subject of scientific debate today [19].

The efforts of modern neuropharmacology are aimed at finding effective molecules that can prevent secondary neuronal damage, which is the most promising target of the effect of pharmaceuticals at acute brain injury by far. Primary neuroprotection is aimed at inhibiting rapid reactions of the glutamate calcium cascade. The greatest hopes in this direction are laid on NMDA receptor blockers. Promising for further study is a compound that has neuroprotective properties, synthesized under the guidance of academician M.O. Lozynskyi in the Institute of Organic Chemistry NAS of Ukraine, derivative of adamantane 1-adamantylethyloxy-3-morpholino2-propanol hydrochloride (laboratory code is YUK-1, conditional name is Ademol) [20,21,22]. The impetus for in-depth study of the cerebroprotective effect of Ademol was the fact that it is a low-affinity non-competitive blocker of the polyamine site of the NMDA receptors of the ionophore complex of pyramidal neurons of the hippocampus with very fast kinetics of NMDA receptors release [23].

The neuroprotective effects of Ademol are, to some extent, related to the presence of a stimulating effect on cerebral blood supply. Studies have shown the presence in Ademol of a stimulating effect on cerebral blood flow in the basin of the internal carotid artery at acute cerebral blood circulation disorder by ischemic type [24], similar positive effect on cerebral hemodynamics was also obtained on models of hemorrhagic stroke [25]. It should be noted that integrative indicators of the effect of the neuroprotector on the ischemic brain are, along with 
Original research

the decrease in mortality, the rapid elimination of neurological deficit and the restoration of cognitive-mnestic functions, which was the case in studies of Ademol [26].

That is why it was advisable to evaluate the cerebroprotective properties of intensive care of TBI by Ademol of a certain conditionally effective dose of $2 \mathrm{mg} / \mathrm{kg}$ $\mathrm{i} / \mathrm{v}$ on the dynamics of the neurological status of rats in comparison with the magnesium sulfate solution, which showed a positive effect on the course of brain injury, however, according to the result of the meta-analysis, it requires further study (table 1).

The study showed that both at the end of the first day of TBI and after 8 days after pathology modeling, rats had severe neurological changes: convulsions, paralysis, paresis and ptosis, which did not disappear completely in the control pathology group. However, on points on a scale of S.R. McGrow, neurological deficiency in rats with severe TBI, which received only $0.9 \% \mathrm{NaCl}$ solution at $24 \mathrm{~h}$ after injury, was comparable to the one, occurring at day 8 , but was not significantly different. Thus, for animals that received only

Table $1 \quad 0.9 \% \mathrm{NaCl}$ solution (control pathology)

Effect of course infusion of Ademol and magnesium sulfate on neurological deficiency in rats with traumatic brain injury on the 8th day of the experiment $(M \pm m, n=10)$

\begin{tabular}{|c|c|c|}
\hline \multirow[t]{2}{*}{ Group of animals } & \multicolumn{2}{|c|}{$\begin{array}{c}\text { Neurological deficit on a scale of } \\
\text { S.R. McGrow }\end{array}$} \\
\hline & 1 day & 8 day \\
\hline $\begin{array}{l}\text { Pseudoperated animals }+0.9 \% \\
\mathrm{NaCl} \text { solution }\end{array}$ & $0.3 \pm 0.25$ & $0.00 \pm 0.00$ \\
\hline $\begin{array}{c}\mathrm{TBI}+0.9 \% \mathrm{NaCl} \text { solution (control } \\
\text { pathology) }\end{array}$ & $16.25 \pm 0.25$ & $15.80 \pm 0.62$ \\
\hline $\begin{array}{l}\text { TBI + Ademol, } \\
2 \mathrm{mg} / \mathrm{kg} \mathrm{i} / \mathrm{v}\end{array}$ & $12.3 \pm 0.23^{\circ *} \bullet$ & $\begin{array}{c}9.40 \pm 0.29 \\
\mathrm{o} *\end{array}$ \\
\hline $\begin{array}{c}\text { TBI }+ \text { magnesium sulfate, } \\
250 \mathrm{mg} / \mathrm{kg} \mathrm{i} / \mathrm{v}\end{array}$ & $15.33 \pm 0.30^{\circ *}$ & $12.30 \pm 0.31^{\circ *}$ \\
\hline
\end{tabular}

Notes:

1. TBI - traumatic brain injury;

$2 .^{\circ}-p<0.05$ relative to pseudoperated animals;

$3 .{ }^{*}-\mathrm{p}<0.05$ relative to the control pathology group;

4. $\bullet-p<0.05$ relative to the magnesium sulfate group $(250 \mathrm{mg} / \mathrm{kg} \mathrm{i} / \mathrm{v})$. as TBI therapy, the average score on the scale of S.R. McGrow at day 1 and day 8 of the study was: $16.25 \pm 0.25$ and 15.80 \pm 0.62 respectively, which corresponds to a severe degree of neurological symptoms and correlates with a high mortality rate $(90 \%)$. It should be noted that the use of $0.9 \% \mathrm{NaCl}$ solution for 8 days did not cause the decrease in mortality and neurological deficits, respectively.

Analyzing the effect of course therapy with Ademol solution on the degree of reduction of neurological deficiency, it can be noted that, by this property, the study drug outweighed the magnesium sulfate solution on the first day of application by $24 \%(\mathrm{p}<0.05)$. Analyzing the effectiveness of the therapy of TBI on the eighth day of observation, the study drug reliably outweighed the magnesium sulfate solution by $30 \%$ - when the average score on

Table 2 a scale of S.R. McGrow was Influence of course infusion of Ademol and magnesium sulfate on training and memory of rats with traumatic brain injury by conditioned response of passive avoidance test (the end of 8 th day) $(M+m, n=10)$

\begin{tabular}{|c|c|c|}
\hline \multirow{2}{*}{ Group of animals } & \multicolumn{2}{|c|}{ The latent period of entering the dark chamber, sec } \\
\cline { 2 - 3 } & before studying & 24 hours after studying \\
\hline $\begin{array}{c}\text { Pseudoperated animals }+0.9 \% \\
\text { NaCl solution }\end{array}$ & $5.30 \pm 0.42$ & $223.80 \pm 1.66$ \\
\hline TBI $+0.9 \%$ NaCl solution & $19.70 \pm 0.47^{\circ}$ & $48.90 \pm 0.96^{\circ}$ \\
(control pathology) & $(+271.7 \%)$ & $(-78.2 \%)$ \\
\hline TBI + Ademol, & $11.00 \pm 0.28^{\circ *} \bullet$ & $98.80 \pm 2.50^{\circ *} \bullet$ \\
$2 \mathrm{mg} / \mathrm{kg} \mathrm{i} / \mathrm{v}$ & $(+107.5 \%)$ & $(-55.7 \%)$ \\
& {$[-44.7 \%]$} & {$[+102.0 \%]$} \\
\hline TBI + magnesium sulfate, & $15.30 \pm 0.28^{\circ *}$ & $65.0 \pm 1.04^{\circ *}$ \\
$250 \mathrm{mg} / \mathrm{kg} \mathrm{i} / \mathrm{v}$ & $(+188.7 \%)$ & $(-70.9 \%)$ \\
& {$[-22.4 \%]$} & {$[+32.9 \%]$} \\
\hline
\end{tabular}

\section{Notes:}

1. TBI - traumatic brain injury;

$2^{\circ}{ }^{\circ}-p<0.05$ relative to pseudoperated animals;

$3 . *$ - $\mathrm{p}<0.05$ relative to the control pathology group;

4. $\bullet-\mathrm{p}<0.05$ relative to the magnesium sulfate group (250 mg / $\mathrm{kg} \mathrm{i} / \mathrm{v}$ );

5 . In round brackets - changes $(\%)$ relative to the indicator of pseudoperated rats, in square brackets - relative to the indicator of animals with TBI, which were injected $0.9 \% \mathrm{NaCl}$ solution (control group). a scale of S.R. McGrow was
$9.40 \pm 0.29$ (Ademol) versus $12.30 \pm 0.31$ (magnesium sulfate) in the study groups.

Regarding the restoration of mnestic functions at TBI, eight-day treatment of rats with magnesium sulfate solution was inferior to the efficacy of Ademol with a $2 \mathrm{mg} /$ $\mathrm{kg}$ i/v conditionally effective dose, which approximated the results of the conditional reaction of passive avoidance (CRPA) to the results of pseudoperated animals better (table 2).

The latent period of CRPA in rats, treated with Ademol and magnesium sulfate, improved significantly, probably improved relatively: 11.00 and 15.3 compared with control group $19.7(\mathrm{p}<0.05)$ (table 2). 
Studies have shown that the neuroprotective effect of Ademol is associated with a modulating effect on the activity of NMDA receptors, it was also found that the drug has a complex effect, showing the properties of both primary and secondary cerebroprotectors, with significant advantages compared to others, presented in modern pharmaceutical market, neuroprotectors [27]. Acute excitotoxic neurodegeneration, caused by excessive activation of NMDA receptors and pathological reactions of glutamate-calcium damage, develops not only at brain strokes. By far, its determining role in the initiation of secondary damage at traumatic brain injuries has been proved [27]. The results obtained in our study are pathogenetically reasoned and substantially open up the prospects for further research.

\section{Conclusions}

1. Rats with severe TBI experienced severe neurological deficits, impaired learning and memory in the recovery period.

2. The obtained results regarding the correction of neurological deficiency in rats with severe TBI by comparator drugs showed the lack of reliable efficacy of magnesium sulfate at experimental TBI in rats.

3. Ademol had a significantly better effect on the reduction of neurological disorders compared with the magnesium sulfate solution, which was accompanied by an improvement in mnestic functions in animals with TBI.

\section{Список літератури}

1. Majdan M, Plancikova D, Brazinova A, et al. Epidemiology of traumatic brain injuries in Europe: a cross-sectional analysis. Lancet Public Health. 2016 Dec;1(2):76-83.

2. Gardner RC, Dams-O'Connor K, Morrissey MR, Manley GT. Geriatric Traumatic Brain Injury: Epidemiology, Outcomes, Knowledge Gaps, and Future Directions. J Neurotrauma. 2018 Feb 15. DOI: $10.1089 /$ neu.2017.5371.

3. Llompart-Pou JA, Pérez-Bárcena J. Geriatric traumatic brain injury: An old challenge. Med Intensiva. 2019 Jan - Feb;43(1):44-46.

4. Arun P, Ariyannur PS, Moffett JR et al. Metabolic acetate therapy for the treatment of traumatic brain injury. J Neurotrauma. 2010;27(1):293-98.

5. Семененко АI, Кобеляцький ЮЮ, Кондрацький БО, Семененко НО. Оцінка терапевтичної ефективності $0,9 \%$ розчину $\mathrm{NaCl}$ та розчину маніту в пацієнтів із гострим ішемічним інсультом за неврологічним дефіцитом. Медицина неотложных состояний. 2016;6 (77):98-101.

6. Weissenberger CA, Sirén AL. Experimental traumatic brain injury. Exp Transl Stroke Med. 2010;2:2-16.

7. Nishizawa Y. Glutamate release and neuronal damage in ischemia. Life Sci. 2001; 69:369-81.

8. Cooper AJ, Jeitner TM. Central role of glutamate metabolism in the maintenance of nitrogen homeostasis in normal and hyperammonemic brain. Biomolecules. 2016;6(2):390-98.

9. Burd I, Welling J, Kannan G, Johnston M. Excitotoxicity as a Common Mechanism for Fetal Neuronal Injury with Hypoxia and Intrauterine Inflammation. Adv Pharmacol. 2016;76:85-101.

10. Olloquequi J, Cornejo-Córdova E, Verdaguer E, et al. Excitotoxicity in the pathogenesis of neurological and psychiatric disorders: Therapeutic implications. J Psychopharmacol. 2018;32(3):265-75.

11. Буреш Я, Бурешова О, Хьюстон Д. Методики и основные эксперименты по изучению мозга и поведения. М. : Высшая школа;1991:527 с.

12. Лапач СН, Чубенко АВ, Бабич ПН. Статистические методы в медико-биологических исследованиях с использованием
Excel. К. : МОРИОН, 2000:320 c.

13. Long B, Koyfman A. Secondary Gains: Advances in Neurotrauma Management. Emerg Med Clin. - North Am. 2018;36(1):107-33.

14. Ameliorate JL, Ghabriel MN, Vink R. Magnesium enhances the beneficial effects of NK1 antagonist administration on blood-brain barrier permeability and motor outcome after traumatic brain injury. Magnes Res. 2017;30(3):88-97.

15. Arango MF, Bainbridge D. Magnesium for acute traumatic brain injury. Cochrane Database Syst Rev. 2008;4:5400-08.

16. Vujovic KS, Vuckovic S, Durovic A, et al. Inhibition of neuronal nitric oxide synthase attenuate the hypothermic effect of ketamine-magnesium sulfate combination in rats. J Therm Biol. 2018;74:1-5.

17. Vink R, Cook NL, van den Heuvel C. Magnesium in acute and chronic brain injury: an update. Magnes Res. 2009;22(3):158-62.

18. Dorhout Mees SM, Leijenaar JF, Algra A, et al. Magnesium in aneurysmal subarachnoid hemorrhage (MASH II) phase III clinical trial MASH-II study group. Int J Stroke. 2008;3(1):63-65.

19. Lingam I, Robertson NJ. Magnesium as a Neuroprotective Agent: A Review of Its Use in the Fetus, Term Infant with Neonatal Encephalopathy, and the Adult Stroke Patient. Dev Neurosci. 2018;40(1):1-12.

20. Пат. на винахід 106032 Україна, МПК (2014.01) С07С 13/615 (2006.01). Фармацевтична композиція 1-адамантилетокси-3-діетиламіно-2-пропанол гідрохлорид або його фармацевтично прийнятних солей для створення лікарських засобів для лікування цереброваскулярної патології / Загорій Г. В., Ходаківський О. А. ; заявник та патентовласник Загорій Г. В. ; № 106032; заявл. 24.12.2013; опубл. 10.07.2014, Бюл. № 13. - 4 c.

21. Пат. на корисну модель 51684 Україна, МПК (2009) C07D 295/084 (2006.01). Застосування 1-(адаманти-1-алкокси)-3-діалкіламіно-2-пропанолів як засобів, які мають церебропротекторну активність / Короткий Ю. В., Степанюк Г. І., Ходаківський О. А., Лозинський М. О., Смертенко О. А., Чорноіван Н. Г. ; заявник та патентовласник Інститут органічної хімії НАН України. - № u 201001439 ; заявл. 12.02.2010 ; опубл. 26.07.2010, Бюл. № 14. - 6 c.

22. Пат. на корисну модель 59354 Україна, МПК (2011.01) C07D 295/084 (2006.01). Застосування 1-(1-адамантил-1-алкоксі)-3-аміно-2-пропранололів, як засобів, які мають кардіопротекторну активність / Короткий Ю. В., Ходаківський О. А., Степанюк Г. І., Чорноіван Н. Г., Лозинський М. О., Смертенко О. А. ; заявник та патентовласник Інститут органічної хімії $\mathrm{HAH}$ України. № u 201013028 ; заявл. 02.11.2010. ; опубл. 10.05.2011, Бюл. № 9. -12 c.

23. Ходаківський ОА. Порівняльна оцінка впливу похідних адамантану сполук ЮК-1 та ЮК-4 на активність NMDA-peцепторів. Клін. фармація. 2011;4:60-63.

24. Ходаківський ОА. Патогенетичне обгрунтування доцільності використання нових похідних адамантану при експериментальній терапії гострої ішемії головного мозку та міокарда (експериментальне дослідження) : автореф. дис. д. мед. н. : спец. 14.03.05 "Фармакологія"; Одеса, 2014. - 24 с.

25. Ходаківський ОА, Жабоєдова НВ, Рокунець ІЛ, та ін. Порівняльна оцінка впливу адемолу та німодипіну на церебральну гемодинаміку в корі головного мозку за умов експериментального субарахноїдального крововиливу. Світ медицини та біології. 2016;3:150-53.

26. Ходаковский АА, Маринич ЛИ, Багаури ОВ. Особенности формирования постреперфузионного повреждения нейронов характеристика модели «ишемия-реперфузия». Новые направления и перспективы развития современной церебропротекторной терапии ишемического инсульта. Врач-аспирант. 2013;3(58):69-76.

27. Ходаковский АА. Нейроморфологическая оценка эффективности адемола в остром периоде модельного нарушения мозгового кровообращения. Человек и его здоровье. 2013;1:32-37.

\section{References}

1. Majdan M, Plancikova D, Brazinova A, et al. Epidemiology of 


\section{Original research}

traumatic brain injuries in Europe: a cross-sectional analysis. Lancet Public Health. 2016 Dec;1(2):76-83.

2. Gardner RC, Dams-O'Connor K, Morrissey MR, Manley GT. Geriatric Traumatic Brain Injury: Epidemiology, Outcomes, Knowledge Gaps, and Future Directions. J Neurotrauma. 2018 Feb 15. DOI: $10.1089 /$ neu.2017.5371.

3. Llompart-Pou JA, Pérez-Bárcena J. Geriatric traumatic brain injury: An old challenge. Med Intensiva. 2019 Jan - Feb;43(1):44-46.

4. Arun P, Ariyannur PS, Moffett JR et al. Metabolic acetate therapy for the treatment of traumatic brain injury. J Neurotrauma. 2010;27(1):293-98.

5. Semenenko AI, Kobeliatskyi YY, Kondratskyi BO, Semenenko NO. Otsinka terapevtychnoi efektyvnosti $0,9 \%$ rozchynu $\mathrm{NaCl}$ ta rozchynu manitu $\mathrm{v}$ patsiientiv iz hostrym ishemichnym insultom za nevrolohichnym defitsytom [Therapeutic efficacy of $0.9 \%$ dissolves $\mathrm{NaCl}$ and dissolves the screen in active individuals with acute ischemic stroke for neurological deficits]. Medytsyna neotlozhnikh sostoianyi. 2016;6 (77):98-101(in Ukrainian).

6. Weissenberger CA, Sirén AL. Experimental traumatic brain injury. Exp Transl Stroke Med. 2010;2:2-16.

7. Nishizawa Y. Glutamate release and neuronal damage in ischemia. Life Sci. 2001; 69:369-81.

8. Cooper AJ, Jeitner TM. Central role of glutamate metabolism in the maintenance of nitrogen homeostasis in normal and hyperammonemic brain. Biomolecules. 2016;6(2):390-98.

9. Burd I, Welling J, Kannan G, Johnston M. Excitotoxicity as a Common Mechanism for Fetal Neuronal Injury with Hypoxia and Intrauterine Inflammation. Adv Pharmacol. 2016;76:85-101.

10. Olloquequi J, Cornejo-Córdova E, Verdaguer E, et al. Excitotoxicity in the pathogenesis of neurological and psychiatric disorders: Therapeutic implications. J Psychopharmacol. 2018;32(3):265-75.

11. Buresh Ya, Bureshova O, Khiuston D. Metodiki i osnovnie eksperymenti po izucheniiu mozgha y povedeniia [Techniques and basic experiments on the study of the brain and behavior]. M. : Visshaia shkola;1991:527 s (In Russian).

12. Lapach SN, Chubenko AV, Babych PN. Statistycheskie metodi v mediko-biolohycheskikh issledovaniiakh $\mathrm{s}$ ispolzovaniem Excel [Statistical methods in biomedical research using Excel]. K. : MORION, 2000:320 s (In Russian).

13. Long B, Koyfman A. Secondary Gains: Advances in Neurotrauma Management. Emerg Med Clin. - North Am. 2018:36(1):107-33.

14. Ameliorate JL, Ghabriel MN, Vink R. Magnesium enhances the beneficial effects of NK1 antagonist administration on blood-brain barrier permeability and motor outcome after traumatic brain injury. Magnes Res. 2017;30(3):88-97.

15. Arango MF, Bainbridge D. Magnesium for acute traumatic brain injury. Cochrane Database Syst Rev. 2008;4:5400-8.

16. Vujovic KS, Vuckovic S, Durovic A et al. Inhibition of neuronal nitric oxide synthase attenuate the hypothermic effect of ketamine-magnesium sulfate combination in rats. J Therm Biol. 2018;74:1-5.

17. Vink R, Cook NL, van den Heuvel C. Magnesium in acute and chronic brain injury: an update. Magnes Res. 2009;22(3):158-62.

18. Dorhout Mees SM, Leijenaar JF, Algra A, et al. Magnesium in aneurysmal subarachnoid hemorrhage (MASH II) phase III clinical trial MASH-II study group. Int J Stroke. 2008;3(1):63-65.

19. Lingam I, Robertson NJ. Magnesium as a Neuroprotective Agent: A Review of Its Use in the Fetus, Term Infant with Neonatal Encephalopathy, and the Adult Stroke Patient. Dev Neurosci. 2018;40(1): 1-12.

20. Pat. na vynakhid 106032 Ukraina, MPK (2014.01)
S07S 13/615 (2006.01). Farmatsevtychna kompozytsiia 1 adamantyletoksy-3-dietylamino-2-propanol hidrokhloryd abo yoho farmatsevtychno pryiniatnykh solei dlia stvorennia likarskykh zasobiv dlia likuvannia tserebrovaskuliarnoi patolohii patolohii [Pharmaceutical composition 1-adamantylethoxy-3-diethylamino-2 propanol hydrochloride or its pharmaceutically acceptable salts for the manufacture of medicines for the treatment of cerebrovascular pathology of pathology]/ Zahorii H. V., Khodakivskyi O. A.; zaiavnyk ta patentovlasnyk Zahorii H. V. ; № 106032; zaiavl. 24.12.2013; opubl. 10.07.2014, Biul. № 13. - 4 s (in Ukrainian).

21. Pat. na korysnu model 51684 Ukraina, MPK (2009) S07D 295/084 (2006.01). Zastosuvannia 1-(adamanty-1alkoksy)-3-dialkilamino-2-propanoliv yak zasobiv, yaki maiut tserebroprotektornu aktyvnist [The use of 1- (adamantyl-1-alkoxy) -3-dialkylamino-2-propanol as a means of cerebroprotective activity] Korotkyi Yu. V., Stepaniuk H. I., Khodakivskyi O. A., Lozynskyi M. O., Smertenko O. A., Chornoivan N. H. ; zaiavnyk ta patentovlasnyk Instytut orhanichnoi khimii NAN Ukrainy. - № u 201001439 ; zaiavl. 12.02.2010 ; opubl. 26.07.2010, Biul. № 14. - 6 s (in Ukrainian).

22. Pat. na korysnu model 59354 Ukraina, MPK (2011.01) S07D 295/084 (2006.01). Zastosuvannia 1-(1-adamantyl-1-alkoksi)-3amino-2-propranololiv, yak zasobiv, yaki maiut kardioprotektornu aktyvnist [The use of 1- (1-adamantyl-1-alkoxy) -3-amino-2 propranolols as agents having cardioprotective activity] / Korotkyi Yu. V., Khodakivskyi O. A., Stepaniuk H. I., Chornoivan N. H., Lozynskyi M. O., Smertenko O. A. ; zaiavnyk ta patentovlasnyk Instytut orhanichnoi khimii NAN Ukrainy. № u 201013028 ; zaiavl. 02.11.2010. ; opubl. 10.05.2011, Biul. № 9. - 12 s (in Ukrainian).

23. Khodakivskyi OA. Porivnialna otsinka vplyvu pokhidnykh adamantanu spoluk YuK-1 ta YuK-4 na aktyvnist NMDA-retseptoriv [Comparative evaluation of the effect of adamantane derivatives of YUK-1 and YUK-4 compounds on NMDA receptor activity]. Klin. farmatsiia. 2011;4:60-63 (in Ukrainian).

24. Khodakivskyi OA. Patohenetychne obgruntuvannia dotsilnosti vykorystannia novykh pokhidnykh adamantanu pry eksperymentalnii terapii hostroi ishemii holovnoho mozku ta miokarda (eksperymentalne doslidzhennia) [Pathogenetic substantiation of expediency of using new adamantane derivatives in experimental therapy of acute cerebral ischemia and myocardium (experimental study)]: avtoref. dys. d. med. n. : spets. 14.03.05 "Farmakolohiia"; Odesa, 2014. - 24 s (in Ukrainian).

25. Khodakivskyi OA, Zhaboiedova NV, Rokunets IL, ta in. Porivnialna otsinka vplyvu ademolu ta nimodypinu na tserebralnu hemodynamiku v kori holovnoho mozku za umov eksperymentalnoho subarakhnoidalnoho krovovylyvu [Comparative assessment of the effects of ademol and nimodipine on cerebral hemodynamics in the cerebral cortex under experimental subarachnoid hemorrhage]. Svit medytsyny ta biolohii. 2016;3:150-53 (in Ukrainian).

26. Khodakovskyi AA, Marynych LY, Bahaury OV. Osobennosty formyrovaniia postreperfuzyonnoho povrezhdeniia neironov kharakterystyka modely «ishemiia-reperfuziia». Novie napravleniia i perspektivi razvityia sovremennoi tserebroprotektornoi terapii ishemycheskoho insulta [Features of the formation of postperfusion neuronal damage is a characteristics of the ischemia-reperfusion model. New directions and prospects of development of modern cerebroprotective therapy of ischemic stroke]. Vrach-aspirant. 2013;3(58):69-76 (in Russian).

27. Khodakovskyi AA. Neiromorfolohycheskaia otsenka effektivnosti ademola $\mathrm{v}$ ostrom peryode modelnoho narushenyia mozghovoho krovoobrashchenyia [Neuromorphological evaluation of the efficacy of ademol in the acute period of model disorders of the cerebral circulation]. Chelovek i eho zdorove. 2013;1:32-37 (In Russian).

\section{Відомості про авторів}

Семененко Святослав Ігорович - к.мед.н., доцент кафедри клінічної фармації та клінічної фармакології Вінницького національного медичного університету ім. М.І. Пирогова, м. Вінниця, Україна. 
Оригінальні дослідження

Хребтій Галина Іванівна - к.мед.н., доцент кафедри внутрішньої медицини, фізичної реабілітації та спортивної медицини Вищого державного навчального закладу України "Буковинський державний медичний університет", м. Чернівці, Україна.

Семененко Андрій Ігорович - д.мед.н., професор кафедри анестезіології, IT та невідкладної медицини Вінницького національного медичного університету ім. М.І. Пирогова, м. Вінниця, Україна.

\section{Сведения об авторах}

Семененко Святослав Игоревич - к.мед.н., доцент кафедры клинической фармации и клинической фармакологии Винницкого национального медицинского университета им. Н.И. Пирогова, г. Винница, Украина.

Хребтий Галина Ивановна - к.м.н., доцент кафедры внутренней медицины, физической реабилитации и спортивной медицины Высшего государственного учебного заведения Украины "Буковинский государственный медицинский университет", г. Черновцы, Украина.

Семененко Андрей Игоревич - д.м.н., профессор кафедры анестезиологии, ИТ и неотложной медицины Винницкого национального медицинского университета им. Н.И. Пирогова, г. Винница, Украина.

\section{Information about the authors}

Semenenko S.I. - PhD in Medical Sciences, Associate Professor of the Department of Clinical Pharmacy and Clinical Pharmacology National Pirogov Memorial Medical University, Vinnytsia, Ukraine.

Khrebtii H.I. - PhD in Medical Sciences, Associate Professor of the Department of Internal Medicine, Physical Rehabilitation and Sports Medicine, Higher Education Institution of Ukraine "Bukovinian State Medical University", Chernivtsi, Ukraine.

Semenenko A.I. - Doctor of Medicine, Professor of the Department of Anesthesiology, IT and Emergency Medicine National Pirogov Memorial Medical University, Vinnytsia, Ukraine.

Надійшла до редакції 02.04.2020

Рецензент - доц. Шутка В.Я.

(C) С.I. Семененко, Г.I. Хребтій, А.І. Семененко, 2020 